2020, Volume 10, International Conference Globalization, Innovation and Development. Trends and Prospects (G.I.D.T.P.), pages: 126-133 | https://doi.org/10.18662/lumproc/gidtp2018/15

\section{Management of Sports Organizations}

\section{Maria Cristina STEFAN ${ }^{1}$, Dorin IANCU* ${ }^{2}$}

${ }^{1}$ Valahia University of Targoviste, Romania,e-mail:

crys07stefan@yahoo.com

2 Valahia University of Targoviste, Romania,e-mail: dorin iancu@yahoo.com Corresponding author
Abstract: Beyond the fact that sport has become a major social phenomenon, it has also turned into an educational approach in the sense that it is, on the one hand, an educational tool imposed by the changes in the minds of the people, on the other hand, a moral reference to education. Sport is more than just a sport, it has become a show involving several categories of actors: sports organizations, trade organizations, spectators, central and local communities. If at the beginning of the last century there were few nonworking organizations over time, their number grew a lot.

Keywords: management of sports organizations; efficient management; sports organizations; sport governance.

How to cite: Stefan, M.C., \& Iancu, D. (2020). Management of Sports Organizations. In I. Panagoreț \& G. Gorghiu (vol. ed.), Lumen Proceedings: Vol. 10. International Conference Globalization, Innovation and Development. Trends and Prospects (G.I.D.T.P.) (pp. 126-133). Iasi, Romania: LUMEN Publishing House. https://doi.org/10.18662/lumproc/gidtp2018/15 


\section{Introduction}

The proposal of a model for improving the management of a sports organization (model 2MEOS) is based on the idea that sport has become a complex phenomenon with economic, political and social connotations. The treatment of the sporting organization as a public entity calls into question the state's elaboration of a policy in the field of making strategic choices available to sports organizations, so obliged to practice rational and effective management to achieve strategic and managerial performance [1]. Such an approach is necessary because the organization, like any organization, must operate on economic principles.

In this context, the study of the organization's internal and external environment is required. Some questions are asked:

- Can the sports organization as a public entity be managed as any lucrative organization?

- Can there be a concordance between the general interest and the profit making in the sports organizations?

- Can we identify, in a sporting environment, factors that influence the performance of sports organizations?

As an objective, it was determined to identify the particularities of the management of sports organizations. It was mentioned in this statement main features of sports organization management [2]:

- The hybrid character of the operation of sports organizations;

The hybrid character of sports organizations' performance is due to the varied character of the complex factors that influence the behavior of the participants in the sporting movement. These factors are of an economic, social and symbolic nature. Hybridization is defined as the crossing phenomenon of two varieties of the same species between two species [3].

There are three reasons underlying sport management:

- the first, associate on the social aspect of sport, which encourages mutual assistance, conviviality, fraternity, cohesion;

- secondly, legal relating to state-sponsored sport policies (training, employment, regulation, provision of free infrastructure and symbolic prices);

- the third, commercial, that regards the economic aspect of sport (selling the sport show, generating the necessary financial resources for both the development of the sports act and its independence from the state).

$V$ arious types of governance of sports organizations; 
Sports organizations have a certain legitimacy that gives them certain characteristics:

First of all, legitimate character is given by public opinion.

Secondly, the need for a certain paradox and a certain ambiguity due to the combination of managerial practices used both in the private and public sectors. This assertion is based on the fact that private organizations carry out sponsorship, patronage, and other actions that define the organization's social responsibility.

Third, there is a complexity of organizational forms in the sense of diminishing the differences in functioning between the public and private sectors.

The governance of these organizations is defined as the participation of all parts involved in the sporting act, each pursuing a certain interest. These are the state, shareholders, employees, managers, athletes, etc. Three types of governance within sport organizations are identified [4]:

- a governance based on a clear differentiation of the roles of the various actors of the organizations;

- governance based on relative position differentiation and employee participation (employees and technicians); by volunteers.

- undifferentiated governance of each actor's position and work done

- Diversity and interdependence of the actors involved, to the good work of the sports organization.

The diversity and interdependence of actors refers to a form of complex collaboration if different actor's individual expectations are taken into account. By stakeholder, we mean any group or individual who may or may be affected by an organization's goals [5]. Thus, in this context, it can be argued that at the base of any organization there are four categories of stakes that refer to political factors, structural factors, cultural or symbolic factors and the organizational brand.

- Increasing of the professional character of the managerial act in a sports organization;

Professionalizing the management of sports organizations is a concrete way of professionalizing the management of an organization. This is based on the idea of transforming the position of manager into an independent profession [6]. The criterion of quality of management will always be practical success and entrepreneurial activity [7]. Professionalizing the management of sports organizations is a process of rationalizing their activity, which is done in two ways:

- developing and promoting professional-group strategies to control the way in which work is done and the conditions of good development of activities in organizations;

- raising and specializing levels of skills. 
Professionalization of sports organizations' management is addressed from the perspective of the defining elements of an organization [8].

- the structure, in the sense of considering the organization as a central associative project (the effectiveness of the organization depends on the implementation of participatory management);

- activities in terms of their development and diversification;

- members of the collectivity, by taking into account the human resources in the process of making the organization more efficient (volunteers and professionals

\begin{tabular}{|c|c|}
\hline $\begin{array}{l}\text { Political factors } \\
\text {-The characteristics of } \\
\text { guardianship power } \\
\text {-Personality } \\
\text {-Strategy }\end{array}$ & $\begin{array}{l}\quad \text { Structural Factors } \\
\text { - Organizational structures; } \\
\text { - Management systems and } \\
\text { procedures; } \\
\text { - Systems of motivation, control, staff } \\
\text { selection, management, career; } \\
\text { - Ideology and other established } \\
\text { symbols; } \\
\text { - Formal organization of time and } \\
\text { space. }\end{array}$ \\
\hline $\begin{array}{l}\text { Cultural or symbolic } \\
\text { factors } \\
\text { - Myths, history; } \\
\text { - Rites, enterprise culture, } \\
\text { taboos; } \\
\text { - Informal social structure; }\end{array}$ & $\begin{array}{l}\text { The organizational brand } \\
\text { - The image of the enterprise; } \\
\text { - The image of the job and skills; } \\
\text { - Image of org anizational status } \\
\text { (power levels); }\end{array}$ \\
\hline
\end{tabular}

Figure 1. The stakes of a sport organisation [9]

\section{Paradigm E.S.L. (economic-social-legal)}

Concluding, the management of sport can be defined as "the art and the science of coordinating and managing non-working organizations whose organization must ensure the equilibrium of functionalities of general interest, under the conditions of accepting their functioning on economic 
principles" [10]. Such a definition of sport management determines highlighting of ESJ which is at the basis of its understanding. (Figure.2.).

The unitary character of the organization of sport both at national and local level

L (Legal)
Providing efficient and effective techniques that allow low-cost goals to be met; Optimizing allocated budgets;

\section{E (Economic)}

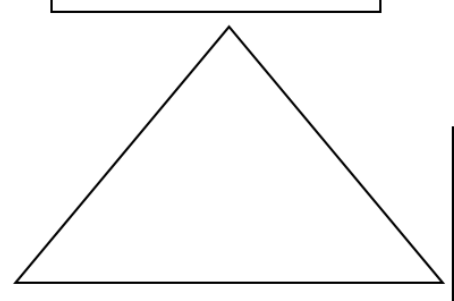

Sport approached as:

- means of social cultural cohesion;

- means of social peace;

- means of motivating the staff;

\section{S (Social)}

Figure 2. ESL Paradigm of sports management

This paradigm can be explained by the fact that sports organizations form a specific system of organizations in a certain hierarchy in which relationships are established between the actors involved. One can therefore speak of a hierarchical, vertical system from the top down [11]. For Romania, the national system of physical education and sports includes sport structures formed by the administration for sport (MECTS, COR, ANS, DJS) and sporting structures, it means sports organizations known under different names: associations, clubs, federations, leagues, etc. (Figure 3). 


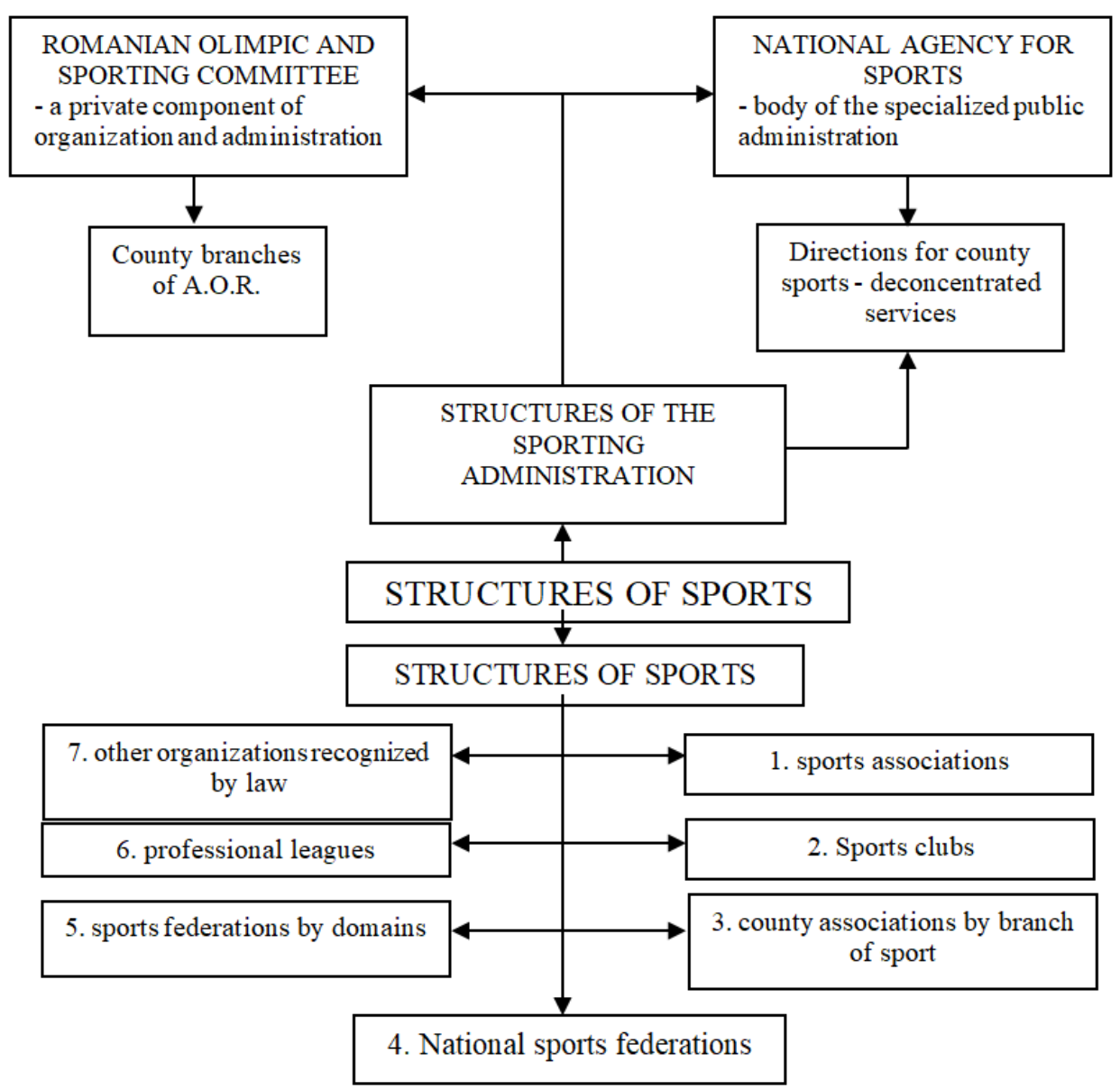

Figure 3. The specialized organizations within the national system of physical education and sport [12]

Our scientific approach is to study school sports clubs whose management needs to be more efficient.

For these are considered three fundamental criteria:

- reliability in the functioning of organizational mechanisms;

- interdependence in the establishment of relations between the operating mechanisms of functioning of sports organizations;

- system consistency. 


\section{Conclusions}

All these criteria are at the basis of the federalization process of sports organizations, which establishes a certain hierarchy that is respected at all levels: federal headquarters, professional league, regional leagues, regional committees, clubs. Such a system is based on a stake: managing it from bottom to top, imposing on each level the ability to innovate and implement these innovations. In fact, designing performance mechanisms is the main objective of the proposed model. Understanding through Performance "the set of means; processes, skills and quality required to achieve the desired results [13]. Performance gains are based on the ability of sports organizations to acquire and transform human, financial and material resources to achieve their goals. Performance is conceived as a set of results for the organization, valued according to the expectations of each part involved in the organization. Each involved part attaches some importance to the results of the organization.

The performance of the sports organization, as in any organization, is characterized by the multidimensionality that legitimizes and identifies a particular organization: results, human resources, financial performance, innovation, internal communication, volume and quality of service, communication with the media [14].

Measuring these indicators is not effective in determining the overall performance of a sports organization. It must have its hybrid character that requires a social balance. Thus, we can identify several categories of indicators. It is proposed to use the Bayle methodology that measures and compares six categories of indicators [15].

- statutory performance;

- internal social performance;

- societal performance;

- economic and financial performance;

- promotional performance

- organizational performance.

The Bayle methodology is considered to be more complete because different stakeholders are considered towards a sports organization.

\section{References}

[1]. Ohl F, Tribou G. Les marches du sport: consommateurs et producteurs. Paris: Armand Colin; 2004.

[2]. Chappelet JL, Bayle E. Strategic and performance management of Olympic sport organizations. United Kingdom: Human Kinetics; 2005. 
[3]. Guyon N, Maurin É. Démocratisation de l'école et persistence des inégalités. Economie et Statistique, Programme National Persée. 1997; 306: 27-39.

[4]. Bayle E. La mesure de la performance des organizati8on à but non lucratif: proposition d'une nouvelle method appliqué au federations sportives nationales. Gestion. 2000; septembre-octombre, 5.

[5]. Freemen RE. Strategie Management: A stakeholder Approach. Boston: Pitman; 1984.

[6]. Vagu P, Stegaroiu I. Scolile de management. Targoviste: Editura Macarie; 1998: 215.

[7]. Drucker P. Practice of management. NY: Harper Business; 1986.

[8]. Fitouri C. La culture de creation dentreprise. Plan de cours; 2010: 17.

[9]. Fitouri C. La culture de creation dentreprise. Plan de cours; 2010: 15.

[10]. Bayle E. Essai de definition des organization sportives: objet, champ,niveaux d'analyse et spécificités des pratiques managériales. STAPS; 2007, 75.

[11]. Friedrich R. Géographie politique. Editions régionales européenes; 1988.

[12]. Mihailescu N. Construirea structurilor sportive. Pitesti: Editura Universitatii din Pitesti; 2008: 109.

[13]. Bayle E. Le spectacle sportif ponctuel: essei d'evaluation. These de doctorat en sciences economiques. Université de Limoges; 2001.

[14]. Fitouri C. La culture de creation dentreprise. Plan de cours; 2010.

[15]. Bayle E. La mesure de la performance des organisation à but non lucrative: proposition d'une nouvelle method appliqué au federations sportives nationales. Gestion. 2000, septembre-octombre, 5. 